DOI: $10.31866 / 2410-1915.20 .2019 .172431$

УДК 028.5:316.7

\title{
ЧИТАННЯ ЯК СКЛАДОВА У ФОРМУВАННІ КУЛЬТУРИ СУЧАСНОЇ МОЛОДІ
}

\section{Прокопенко Людмила Іванівна}

Кандидат культурології, доцент, ORCID: 0000-0002-9095-8428, lyudmila976@ukr.net, Київський національний університет культури і мистецтв, вул. Є. Коновальия, 36, Київ, Україна, 01133

Мета статті - виявити читацькі інтереси студентської молоді, літературні уподобання, що формують їх світогляд та загальну культуру у сучасному інформаційному середовищі.

Методи дослідження. У дослідженні застосовано методи наукового пізнання: логіко-аналітичний, спостереження, емпірично-теоретичний, описовий, узагальнення.

Висновки. У результаті дослідження здійснено культурологічний аналіз читацьких інтересів молоді та впливу читання на їх світогляд. Незважаючи на переваги сучасних інноваційних технологій, читання залишається складовою у формуванні культури сучасної молоді, задоволенні освітніх та інформаційних потреб. Розвиток читацької культури залежить від читацької компетентності, розуміння змісту прочитаного, мотивації до читання. Спостерігається інтерес молоді до літератури психологічного, психоаналітичного, мотиваційного змісту, що сприяє внутрішньому становленню, впевненості в собі, самоствердженню та $є$ запорукою подальшого формування духовних цінностей особистості. Незважаючи на інформаційні потоки, які формують вплив на масову аудиторію, її інформаційну залежність, книга залишається провідною константою культури та є духовною і матеріальною складовою життя суспільства, а формування читацького інтересу є елементом читацької культури.

Ключові слова: читання; читацькі інтереси; читацькі потреби; читацька культура; інформаційне суспільство; соціальні мережі.

\section{Вступ}

Сучасне інформаційне суспільство існує в епоху нон-технологій (non-digital era), що активно вливають на всі сфери суспільного життя. Інформація накопичується у світі щосекунди і $€$ невід’ємним ресурсом у повсякденній діяльності людини. Одним із критеріїв інформованості соціуму $є$ читання, яке сприяє у збагаченні знаннями, самоосвіті, розширює світогляд, допомагає у вирішенні внутрішніх конфліктів людини, розвиває особистість та $є$ основним чинником у формуванні інтелектуально розвинутого суспільства.

Актуальність теми визначається необхідністю здійснити культурологічний аналіз ролі читання, впливу читацьких інтересів на

(c) Прокопенко Л. І., 2019 
формування культури та світогляду сучасної молоді, що обумовлено кризою читання в умовах сьогодення.

Рівень культури та освіти кожного громадянина $є$ одним із ключових показників успішного національного розвитку, конкурентоспроможності держави на світовому ринку, як зазначає Т. Вилегжаніна (2015, с. 4).

Сучасні канали поширення інформації - медіа платформи (зокрема, мобільні платформи, інтернет-платформи 3MI, Kindle-платформа ((Р)еволюція книг, 2019) для читання електронних книг) $є$ новими комунікаційними платформами взаємодії з читачами, засобами пошуку та швидкого доступу до необхідних джерел, електронних текстів.

Незважаючи на інформаційні потоки, які формують вплив на масову аудиторію, іï інформаційну залежність, книга залишається провідною константою культури та $є$ духовною і матеріальною складовою життя суспільства. Формування читацького інтересу, внутрішніх якостей особистості, вміння орієнтуватися в інформаційних потоках є елементами читацької культури. Так, О. Ісаєва визначає читацьку культуру «... як складову частини загальної культури особистості, комплекс знань, умінь і почуттів читача, що передбачає свідомий вибір тематики читання, його системність $з$ метою повноцінного і глибокого сприйняття та засвоєння літературного тексту» (Ісаєва, 2004, с. 5).

На думку експертів, молодь читає мало, що відображається на загальному рівні освіченості населення (Москвичова, 2019). Дослідниця О. М. Циганок зазначає, що серед факторів, які спричинили падіння читацької культури, а також спадання інтересу до читання $€$ : «зниження економічного та морально-культурного рівня життя нашого суспільства; засилля мас-медійної культури; захоплення сучасної молоді комп’ютерними технологіями та Інтернетом; відсутність комплексної програми розвитку читацької культури особистості» (Циганок, 2019, с. 304).

Об’єктом нашого дослідження є студентська молодь віком 18-25 років кафедри інформаційних технологій Київського національного університету культури і мистецтв та їх читацькі інтереси. Предмет - читання як складова формування культури сучасної молоді.

Аналіз наукових розвідок констатує, що читання займає чільне місце у формуванні культури духовних потреб, є засобом самовдосконалення та інтелектуального мислення особистості. Особливо актуальними ці питання $є$ у сучасному інформаційному суспільстві, коли на традиційні культурні цінності впливають засоби масової культури, що призводить до духовної кризи та культури мислення індивідууму.

На сторінках фахових періодичних видань, монографіях, збірниках, дисертаційних дослідженнях висвітлені проблеми читання у працях вітчизняних і зарубіжних вчених: О.Бортнюк (популяризація читання серед молоді) (Бортнюк, 2019), В.Бородіної (теоретичні, технологічні й організаційні засади читацького розвитку особистості) (Бородина, 2007), Т. Булах (популяризація та підтримка читання) (Булах, 2019), Т. Вилегжаніної (проблеми просування читання в сучасному інформаційному суспільстві; 
криза читання) (Вилегжаніна, 2011; Вилегжаніна, 2015), О. Гавелі (читацькі інтереси студентської молоді) (Гавеля, 2012), О. Ісаєвої (технологія розвитку читацької діяльності старшокласників при вивченні зарубіжної літератури) (Ісаєва, 2004), Т. Новальської (читачезнавство) (Новальська, 2005), В. Медведєвої (проблеми читання, популяризація книги) (Медведєва, 2019), Т. Проценко (інформаційна культура читачів) (Проценко, 2014), М. Самохіної (читання молоді) (Самохіна, 2019), О. Циганок (розвиток інтересу до книги та читання) (Циганок, 2019).

\section{Мета статті}

Метою статті є виявлення читацьких інтересів молоді, літературні уподобання, що формують їх світогляд та загальну культуру у сучасному інформаційному середовищі за результатами анкетування студентської молоді.

\section{Виклад матеріалу дослідження}

Проблема читання та його вплив на формування особистості у полі зору як вітчизняних так і зарубіжних науковців, дослідників, практиків бібліотечних установ, соціологічних служб, інформаційних центрів, громадських організацій досліджується не одне десятиліття.

Перенасичення засобами інтернет-середовища низькопробними інформаційними повідомленнями, формують у молоді псевдоідеали, впливають на сприйняття всесвіту, втрату духовних цінностей, етичних та моральних орієнтацій.

В умовах сьогодення, коли більшість простору людини займають соціальні мережі, виникають питання: що читає сучасна молодь? як підвищує свій інтелектуальний розвиток? Що впливає на духовний розвиток молодого покоління і яке місце займає у його формуванні книга? Нами (кафедра інформаційних технологій) було проведено анкетування серед студентів та молодих дослідників факультету інформаційної політики та кібербезпеки, щодо виявлення читацьких інтересів сучасної молоді та їх літературних уподобань.

На запитання «Які соціальні мережі Ви використовуєте для задоволення інформаційних і читацьких потреб?», майже 90\% респондентів відповіли, що надають перевагу таким соціальним мережам, як: Facebook (обмін думками про прочитану книгу, поради друзів, букчеленджі (Book challenge), книжковий флешмоб читай українське, запрошення видавництв на авторські зустрічі, тощо), Google+; Google Академія (у відповідях молодих науковців-дослідників); Viber, Instagram, Telegram (обмін думками про прочитану книгу, поради друзів); Вікіпедія; сайти бібліотек (зокрема е-бібліотеки, е-каталоги), книгарень, видавництв; інформаційні сайти новин, YouTube-канали (Аудіокнига.UA). Водночас, більшість респондентів надали відповіді, що використовують соціальні мережі для прагматичного читання (навчання, підготовка до самостійних робіт), переважно це - 
наукова, науково-популярна література; для відпочинку, дозвілля та духовного пізнання обирають - традиційну книгу (художня література, література для розширення світогляду).

На запитання: «До яких джерел інформації найчастіше звертаєтесь?», у відповідях респондентів переважали - електронні (80\%), друковані (близько 20\%, переважно звертаються із прагматичним читанням, для самоосвіти, підготовки до сесії, самостійних робіт, написання наукових робіт).

За галузями знань опитуваних цікавить література 3 питань релігії, культури освіти, мистецтва, історії, суспільних наук, психології, політики, права, економіки, філософії, мовознавства. Переважає художня література (українська, російська, країн світу).

За видами видань, більшість опитуваних надають перевагу художній (50\%); довідковій (30\%); навчальній (40\%); науково-популярній (30\%); науковій (20\%). За мовою видання: переважає література українською мовою; далі - російською; іноземними мовами (англійська, французька, іспанська, корейська). За типами видань найпопулярнішою $є-$ книга, серед періодичних видань - журнали.

На запитання «Ваш улюблений письменник, улюблена книга» відповіді респондентів були найактивнішими, що наводить на позитивну думку, щодо сталого інтересу до читання. Серед українських письменників улюбленими у молоді є сучасні автори: Андрій Любка («Карбід»); Люко Дашвар («Молоко 3 кров’ю», ПоКров»), Сергій Жадан («Месопотамія», «ДНК», «Депеш Мод. Ще одна розмова»), Ліна Костенко («Триста поезій»), Володимир Лис («Століття Якова»), Марія Матіос («Солодка Даруся»), Ілона Волинська та Кирило Кащеєв («Ірка Хортиця»), Андрій Кузьменко («Я, Побєда і Берлін», «Я, Паштет і армія») та ін.

Твори зарубіжних письменників мають більшу частку активності респондентів, серед відповідей яких улюблені твори класиків: Шарлотти Бронте «Джейн Ейр», Антуана де Сент-Екзюпері («Маленький принц»), Агати Крісті («Вбивство у східному експресі»), Джека Лондона; Джейн Остін («Гордість та упередження»), Еріх Марії Ремарк («Три товариша», «Тріумфальна арка»), Джерома Селінджера («Над прірвою у житі»), Оскара Уайльда «Портрет Доріана Грея», Френсіса Скотта Кі Фіцджеральда («Великий Гетсбі»), Ернеста Хемінгуея («Старий і море»). Серед сучасних зарубіжних авторів у колі читацьких інтересів переважно: Чарльз Буковськи («Жінки»), Джон Грін («Провина зірок», Урсула Кребер Ле Гуін («Чарівник Земноморя»), Ребекка Донован («Жити, щоб любити»), Ален Карр «Легкий спосіб кинути курити», Стівен Кінг, Марк Леві («Діти свободи»), Харукі Муракамі («Норвежський ліс»), Іен Мак»юен («Спокута»), Джоджо Моєс («До зустрічі з тобою»), Стів Харві («Діяти як жінка, думати як чоловік»), Маріам Петросян («Будинок у якому...»), Джоан Роулінг (серія книг про Гаррі Поттера, «Шовкопряд»), Пола Хокінс («Дівчина у потягу»), Ренсома Ріггза («Дім дивних дітей»), Гері Чепмен («П’ять мов любові»), твори Роберта Лоуренса Стайна; К.-А. Такер («Одна маленька брехня), Джейн Хокінг та ін. Серед російської літератури у читацьких інтересах твори 
класиків: Івана Тургенєва («Батьки і діти»), Михайла Булгакова («Майстер i Маргарита»), а також сучасних письменників: Гаврила Троєпольського («Білий Бім Чорне вухо»); фантастика Алекса Коша; Макса Фрай («Хроніки Ехо», «Сновидіння Ехо»); твори Аркадія і Бориса Стругацьких («Складно бути богом»; он-лайн аудіо-книги Євгенія Прошкіна та Олега Овчиннікова («Смертники»); он-лайн аудіо-книги Олексія Пєхова («Хроніки Сіали») та ін.

На запитання: «Яку книгу порадите почитати друзям?», респонденти надали відповіді з рекомендаціями щодо прочитання книг, зважаючи на власні уподобання, серед яких: Майкл Бонд «Ведмедик Паддінгтон»; Ден Браун («Код да Вінчі»); Шарлотта Бронте («Джейн Ейр»); Чарльз Буковськи («Голлівуд»); Михайло Герчик («Вітер рве павутину»); Деніел Кіз («Квіти для Елджернона»); Роберт Кіосакі та Шерон Летчер («Багатий тато. Бідний тато»); Кен Кізі («Над зозулиним гніздом»); Руслан Нарушевич («Жінка і чоловік. На шляху до щастя»); книги Роберта Лоуренса Стайна; комедійні твори Джуді Картера («Біблія гумору»), Ліз Колі («Красуня 13»); Джоан Роулінг (серія книг про Гаррі Поттера, «Шовкопряд»), твори Еріх Марії Ремарк; Грегорі Девід Робертс («Шантарам»); Карлос Руї Сафон («Гра янгола»); Олександр Солженіцин («Архіпелаг ГУЛАГ»); Гаррієт Бічер-Стоу («Хатина дядька Тома»); Анджей Сапковський («Відьмак»); К.-А. Такер («Одна маленька брехня); Іван Тургенєв («Батьки і діти»); Макс Фрай («Хроніки Ехо», «Сновидіння Ехо»); видання німецького психоаналітика Еріха Фрома та ін.

Зауважимо, що студенти, вікова категорія яких 18-19 років, досить активно відповідали на запитання щодо читацьких інтересів та літературних вподобань. У більшості відповідей, на запитання «Остання прочитана книга», переважно твори: австралійського письменника Ніка Вуйчіча («Життя без обмежень. Шлях до неймовірно щасливого життя»), Шарлотти Бронте «Джейн Ейр», Елізабет Гілберт («Їсти, молитися, кохати»), Володимира Гінди та Ярослава Файзуліна («Україна у вогні минулого століття»), Івана Котляревського («Енеїда»), Пауло Коельо («Алхімік»), Марка Менсона («Тонке мистецтво пофігізму»), Станіслава Лема («Соляріс»), Террі Пратчетта («Рухомі картинки»), американського письменника Роберта Лоуренса Стайна («Брехуха»), американського письменника, психолога Наполеона Гілла («Думай і багатій»), Поли Хокінс («Дівчина у потягу»), американського психоаналітика Карен Хорні («Невроз і особистісне зростання. Боротьба за існування»), американського психолога, литовської письменниці Рути Шепетис («Поміж сірих сутінків»), письменника Ірвіна Ялома («Шопенгауер як ліки») та ін. У цьому віці молодь цікавиться психологією особистості, отже, і відповіді засвідчують сталий інтерес до жанру психології, психоаналізу, філософії саморозвитку та мотивації до успішного життя, а також подальшої самореалізації в умовах сьогодення. Ця категорія студентів, на запитання «Шо порадите прочитати молодшому поколінню?» рекомендують «багато читати для визначення улюбленого жанру» та радять: фентезі, книги з етикету, для саморозвитку та самовдосконалення. Серед видань, які пропонують прочитати другокурсники: цикл книг «поліпшення» якості життя, психотерапевта, 
психолога - Валерія Синельникова («Щеплення від стресу Або як стати господарем власного життя»), бестселер російського письменника Дмитра Хари («ПШ»), твори британського письменника гумористичних романів у жанрі фентезі Террі Пратчетта, серію книг білоруської письменниці у жанрі фентезі Ольги Громико, книги американського письменника у жанрі жахів і фентезі Роберта Лоуренса Стайна (або Р. Л. Стайна), японського мангаки Кентаро Міура («Берсерк»), американського журналіста Шрейера Джейсона («Кров, піт і пікселі»), американського письменника, педагога Дейла Карнеги («Як здобувати друзів і впливати на людей») та ін.

Зокрема, студенти других курсів радять для прочитання молодшому поколінню твори категорії нон-фікшн (non-fiction) - літературний жанр, сюжет якого побудовано на реальних подіях та фактах. Зауважимо, що ця категорія респондентів, яка відведена до «молодшої» групи опитуваних, була нам особливо цікавою, з огляду на гіпотезу щодо «кризи читання», «не читають взагалі», а також дослідженнями останніх років щодо втрати ролі читання у сучасному суспільстві, зменшення читацької активності, особливо серед сучасного покоління, відтоку інтересу до читання, в умовах інформаційної глобалізації, що впливають на мислення, читацьку культуру тощо.

\section{Висновки}

Отже, серед читацьких інтересів студентської молоді переважна більшість творів авторів-сучасників. У колі уподобань - література, яка відображає реальні події, фантастика (фентезі і казки), а також видання 3 психології, психотерапії, психоаналізу, філософії. Також, переваги і традиції у читанні мають серед молодого покоління і онлайн аудіо-книги, а також видання, за мотивами яких знято кінофільми.

Зауважимо, що переважна більшість відповідей респондентів окреслює інтерес молоді до літератури психологічного, психоаналітичного, мотиваційного змісту, що сприяє внутрішньому становленню, впевненості в собі, самоствердженню та $\epsilon$ запорукою подальшого формування духовних цінностей особистості. Потреба у цьому жанрі видань викликана зовнішніми чинниками у суспільстві, індивідуальними внутрішніми емоційними переживаннями (відволіктися від життєвих проблем, знайти відповідь на хвилююче запитання), роздумами, віковими особливостями молоді, тощо.

У задоволенні своїх інформаційних та читацьких потреб молодь надає перевагу інноваційним технологіям, зокрема - соціальним мережам. Водночас, більшість вважають традиційну книгу - основним джерелом задоволення своїх духовних потреб. Сторінки Facebook, Instagram, Telegram $\epsilon$ інтерактивними платформами, де молодь обговорює прочитані книги, діляться враженнями про події, описані у них та рекомендують друзям. Ці інтернет-комунікації є посередниками у формуванні читацьких смаків та вибору книг. Щодо переваг традиційної книги та сучасних інноваційних технологій (он-лайн читання аудіо-книг, перегляд YouTube-каналів та молодіжних блогів), відповіді молоді розділились навпіл (50/50\%). 
Відповіді респондентів засвідчують, що молодь читає, незважаючи на інноваційні процеси у сучасному суспільстві (доступ до нових технологій), а також на зайнятість (навчання, робота). Переваги соціальних мереж домінують і займають першу сходинку при швидкому пошуку інформації, друга сходинка - друкована книга. У сучасному мобільному суспільстві переважають атрибути зручності, тому молодь читає он-лайн на електронних носіях (смартфони, планшети, рідери), їдучи на роботу в транспорті, подорожуючи тощо), водночас, наголошуючи в анкетах дослідження, що ніщо не може замінити традиційної книги. Адже результатом прочитаного є вміння критично мислити, розуміти зміст та аналізувати події, оскільки книга $є$ предметом інтелектуальної діяльності людини.

Розвиток читацької культури залежить від читацької компетентності, розуміння змісту прочитаного, мотивації до читання. Безумовно, мотивацією до читання у молоді є навчальні, пізнавальні, самоосвітні, естетичні, емоційні чинники. Також одним із мотиваційних факторів $€$ мода на читання.

На жаль, більшість світогляду молодого покоління формується під впливом 3MI, соціальних мереж, що впливають на їх інтелектуальний рівень, розумову і емоційну активність. Водночас, на противагу цим факторам, вагомою у формуванні молодого покоління $\epsilon$ діяльність бібліотек всіх рівнів і типів. Проекти із залучення до читання книги, книжкові виставки і ярмарки, а також різні інноваційні форми промоції книги і читання (буккросинг, бібліоночі, читання під відкритим небом, автограф-сесії, зустрічі 3 популярними письменниками та ін.), які застосовують у бібліотечній галузі, позитивно сприяють на вирішення проблеми кризи читання.

Узагальнюючи результати дослідження, ми дійшли висновку, що читання залишається складовою у формуванні культури сучасної молоді, освітніх та інформаційних потреб, смаків, пізнання нового та розширення світогляду. Перспективи подальших наукових розвідок вбачаємо у дослідженні проблеми читання та популяризації книги серед молоді, що потребує постійного моніторингу.

\section{Список використаних джерел}

1. Бортнюк О. Круг чтения современной молодежи. Современные исследования социальных проблем. 2015. №8(52). С. 364-370. DOI: 10.12731/2218-7405-2015-8-30/.

2. Бородина В.А. Читательское развитие личности: теоретикометодологические аспекты : дис. ... д-ра пед. наук / Санкт-Петербург. гос. ун-т культуры и искусств, 2007, 371 с.

3. Булах Т. Підтримка читання як запорука розвитку книжкового бізнесу: сучасний вітчизняний та зарубіжний досвід. Вісн. Львів. ун-ту. Серія: Книгознавство, бібліотекознавство та інформ. технології. 2014. Вип. 8. С. 312-317.

4. Вилегжаніна Т. Криза читання як сучасна проблема світового рівня. Бібліотечна планета. 2011. № 4. С. 4-6. 
5. Вилегжаніна Т. Публічні бібліотеки України на зламі століть. Київ : Нац. парлам. б-ка України, 2015. 271 с.

6. Гавеля О. Культурологічний аналіз читацьких інтересів обдарованої молоді вищих навчальних закладів України. Вісник Книжкової палати. 2012. № 3. C. $49-51$.

7. Ісаєва О. О. Теорія і технологія розвитку читацької діяльності старшокласників у процесі вивчення зарубіжної літератури : дис. ... д-ра пед. наук / Нац. пед. ун-т ім. М. П. Драгоманова. Київ, 2004. 446 с.

8. Медведєва В. Читання як опанування нового культурного простору і підвищення особистісної компетентності. Вісник КНУКіМ. Серія: Соціальні комунікації. 2013. Вип. 2. С. 86-91.

9. Москвичова А. Молодь читає, просто інакше - книжковий експерт. Paдio Свобода. Суспільство. 2012. 5 жовт. URL : https://www.radiosvoboda.org/a/24730139. html (дата звернення: 10.05.2019).

10. Новальська Т. В. Український читач у бібліотекознавчих дослідженнях (кінець XIX - початок XXI ст.) : монографія. Київ : Київ. нац. ун-т культури і мистецтв, 2005. 250 с.

11. Проценко Т. Формування інформаційної культури користувачів. Вісник Книжкової палати. 2014. № 3. С. 34-38.

12. (Р)еволюція книг: Що надалі чекає на книжковий бізнес Amazon. $\mathrm{Na}$ chasi. URL : https://nachasi.com/2018/07/23/r-evolyutsiya-knyg/ (дата звернення: 10.05.2019).

13. Самохина М. М. Чтение молодежи: XXI век (по результатам исследований 2001-2011 гг.). Library.ru. URL : http://www.library.ru/1/sociolog/text/article.php?a uid=338 (дата звернення: 10.05.2019).

14. Циганок О. М. Розвиток інтересу до книги та читання - основна складова роботи університетської бібліотеки. Бібліотеки ВНЗ України упроцесі імплементаціі Закону “Про вищу освіту" та інформатизації суспільства. Івано-Франківськ : Наук.-техн. б-ка Івано-Франків. нац. техн. ун-ту нафти і газу, 2015. С. 302-307.

\section{References}

Borodina, V.A. (2007). Chitatelskoe razvitie lichnosti: teoretiko-metodologicheskie aspekty [Readers personality development: theoretical and methodological aspects]. D.Ed. Saint-Petersburg State University of Culture and Arts.

Bortnyuk, O. (2015). Krug chteniya sovremennoi molodezhi [Reading reach of Modern Youth]. Sovremennye issledovaniya sotsialnykh problem, no. 8(52), pp. 364-370.

Bulakh, T. (2014). Pidtrymka chytannia yak zaporuka rozvytku knyzhkovoho biznesu: suchasnyi vitchyznianyi ta zarubizhnyi dosvid [Reading support as a pledge for the development of the book business: modern Ukrainian and foreign experience]. Visnyk Lvivskoho universytetu. Seriia: Knyhoznavstvo, bibliotekoznavstvo ta informatsiini tekhnolohii, issue 8, pp. 312-317.

Havelia, O. (2012). Kulturolohichnyi analiz chytatskykh interesiv obdarovanoi molodi vyshchykh navchalnykh zakladiv Ukrainy [Cultural analysis of readership interests of gifted youth at higher educational institutions of Ukraine]. Visnyk Knyzhkovoi palaty, no. 3, pp. 49-51. 
Isaieva, O.O. (2004). Teoriia i tekhnolohiia rozvytku chytatskoi diialnosti starshoklasnykiv u protsesi vyvchennia zarubizhnoi literatury [Theory and technology of development of readership of senior students in the process of studying foreign literature]. D.Ed. National Pedagogical Dragomanov University.

Medvedieva, V. (2013). Chytannia yak opanuvannia novoho kulturnoho prostoru i pidvyshchennia osobystisnoi kompetentnosti [Reading as the mastering of a new cultural field and increasing personal competence]. Visnyk Kyivskoho natsinalnoho universytetu kultury i mystetstv. Seriia: Sotsialni komunikatsii, issue 2, pp. 86-91.

Moskvychova, A. (2012). Molod chytaie, prosto inakshe - knyzhkovyi ekspert [The youth reads, just in a different way - book expert]. Radio Svoboda. Suspilstvo, [online] October, 5. Available at: <https://www.radiosvoboda.org/a/24730139.html> [Accessed: 10.05.2019].

Novalska, T.V. (2005). Ukrainskyi chytach u bibliotekoznavchykh doslidzhenniakh (kinets $X I X$ - pochatokXXI st.) [Ukrainian reader in librarian studies (end of the XIX - early XXI centuries)] [monograph]. Kyiv: Kyivskyi natsionanyi universytet kultury i mystetstv.

Protsenko, T. (2014). Formuvannia informatsiinoi kultury korystuvachiv [Formation of information culture of users]. Visnyk Knyzhkovoi palaty,no. 3, C. 34-38.

(R)evoliutsiia knyh: Shcho nadali chekaie na knyzhkovyi biznes Amazon [(P)The evolution of books: What is awaiting for the Amazon book business]. (n.d.). $\mathrm{Na}$ chasi, [online] Available at:<https://nachasi.com/2018/07/23/r-evolyutsiya-knyg/> [Accessed:10. 05. 2019].

Samokhina, M.M. Chtenie molodezhi: XXI vek (po rezultatam issledovanii 20012011 gg.) [Reading by youth: 21 th century (according to the results of research of 20012011)]. (n.d.) Library.ru, [online] Available at: <http://www.library.ru/1/sociolog/text/ article.php?a_uid=338> [Accessed:10.05.2019].

Tsyhanok, O.M. (2015). Rozvytok interesu do knyhy ta chytannia - osnovna skladova roboty universytetskoi biblioteky [The development of interest in the book and reading is the core part of the university librarys work]. Biblioteky vyshchykh navchalnyi zakladiv Ukrainy u protsesi implementatsii Zakonu "Pro vyshchu osvitu" ta informatyzatsii suspilstva, pp. 302-307.

Vylehzhanina, T. (2011). Kryza chytannia yak suchasna problema svitovoho rivnia [The crisis of reading as a modern world-class problem]. Bibliotechna planeta, no. 4, pp. 4-6. Vylehzhanina, T. (2015). Publichni biblioteky Ukrainy na zlami stolit [Public libraries at the turn of the century]. Kyiv: National Parliamentary Library of Ukraine. 


\title{
READING AS A COMPONENT IN SHAPING THE CULTURE OF MODERN YOUTH
}

\author{
Liudmyla Prokopenko
}

PhD in Cultural Studies, Associate Professor, ORCID: 0000-0002-9095-8428, lyudmila976@ukr.net, Kyiv National University of Culture and Arts, Kyiv, Ukraine

The aim of the article is to identify the readership interests of students, literary preferences that shape their worldview and general culture in the modern information environment.

Research methods. The research applied methods of scientific knowledge: logicalanalytical, observation, empirical-theoretical, descriptive, and generalization.

Conclusions. As a result of the study, a cultural analysis of the youth `s readership interests and the impact of reading on their worldview have been made. Despite the advantages of modern innovative technologies, reading remains an integral part of shaping the culture of modern youth, meeting educational and informational needs. The development of the reading culture depends on the readers competence, the understanding of the read content, the motivation to read. Youth`s interest in the literature of psychological, psychoanalytic, and motivational content, which contributes to internal formation, selfconfidence, self-affirmation, is a guarantee of the further formation of the moral values of the person. Despite the information flows that shape the influence of the mass audience, its information dependence, the book remains the leading constant in culture and is an intellectual and material component of societys life, and the shaping of readership interest is an element of the reading culture.

Keywords: reading; readership interests; reader needs; reader culture; informationoriented society; social networks.

\section{ЧТЕНИЕ КАК СОСТАВЛЯЮЩАЯ В ФОРМИРОВАНИИ КУЛЬТУРЫ СОВРЕМЕННОЙ МОЛОДЕЖИ}

\section{Прокопенко Людмила Ивановна}

Кандидат культурологии, доцент, ORCID: 0000-0002-9095-8428, lyudmila976@ukr.net, Киевский национальный университет культуры и искусств, Киев, Украина

Цель статьи - выявить читательские интересы студенческой молодежи, литературные предпочтения, формирующие их мировоззрение и общую культуру в современной информационной среде.

Методы исследования. В исследовании применены методы научного познания: логико-аналитический, наблюдения, эмпирически-теоретический, описательный, обобщения. 
Выводы. В результате исследования осуществлено культурологический анализ читательских интересов молодежи и влияния чтения на их мировоззрение. Несмотря на преимущества современных инновационных технологий, чтение остается составляющей в формировании культуры современной молодежи, удовлетворении образовательных и информационных потребностей. Развитие читательской культуры зависит от читательской компетентности, понимания смысла прочитанного, мотивации к чтению. Наблюдается интерес молодежи к литературе психологического, психоаналитического, мотивационного содержания, способствует внутреннему становлению, уверенности в себе, самоутверждению и является залогом дальнейшего формирования духовных ценностей. Несмотря на информационные потоки, которые формируют влияние на массовую аудиторию, ее информационную зависимость, книга остается ведущей константой культуры и является духовной и материальной составляющей жизни общества, а формирование читательского интереса является элементом читательской культуры.

Ключевые слова: чтение; читательские интересы; читательские потребности; читательская культура; информационное общество; социальные сети. 